\title{
Characteristics of water contamination in abandoned coal mines: a case study on Yudong River area, Kaili, Guizhou Province, China
}

\author{
Xiangdong $\mathrm{Li}^{1} \cdot$ Jieying $\mathrm{Cai}^{1} \cdot$ Di Chen ${ }^{1} \cdot$ Qiyan Feng ${ }^{1,2}$
}

Received: 24 December 2019/Revised: 12 July 2021 / Accepted: 1 October 2021/Published online: 11 November 2021

(C) The Author(s) 2021

\begin{abstract}
The seasonal and spatial changes in the chemical composition of the water in abandoned mine drainages and rivers in Yudong River area in the years of 2017-2018 were analyzed. The effects of mine water drainage on the seasonality and physicochemical properties of the river water after mine closure were evaluated, and the feasibility of irrigation using river water and the degree of pollution to farmland were assessed using the Water Quality Standard for Farmland Irrigation. The results show that the mine water has low $\mathrm{pH}$ value $(<3.5-4)$ and high levels of total hardness, $\mathrm{SO}_{4}{ }^{2-}, \mathrm{Fe}, \mathrm{Al}$, and $\mathrm{Zn}$. In addition, the $\mathrm{pH}$ of the mine water is negatively correlated with the presence of other metal ions. The correlation coefficient between the chemical oxygen demand (COD) and Fe reached 0.989. While the pollution levels of Pinglu and Baishui rivers were low, the confluence region of the two rivers was seriously polluted. However, only the levels of Fe and Cd slightly exceeded the Surface Water Environmental Quality Standard after the confluence of Yudong and Chongan rivers. Overall, the heavy pollution type of the confluent river is consistent with mine water pollution. The water quality is slightly better in the dry season compared than in the high-water period. Sulfate and Fe content decreased by 39 and $16 \mathrm{mg} / \mathrm{L}$, respectively, and Cd content decreased two-fold. Despite these findings, this study shows that from 2017 to 2018, the $\mathrm{pH}$ and $\mathrm{Cd}$ content of the rivers at the confluence exceeded the irrigation limit and the water quality continued to deteriorate, which may pose a soil contamination risk. Long-term use of the river for irrigation water may cause toxic elements such as $\mathrm{Cd}, \mathrm{Fe}, \mathrm{Mn}, \mathrm{SO}_{4}{ }^{2-}, \mathrm{Al}$, and $\mathrm{F}^{-}$to enter the food chain, thereby endangering the life and health of villagers in Yudong River area.
\end{abstract}

Keywords Yudong River (Guizhou) $\cdot$ Closed coal mine $\cdot$ Surface water pollution · Irrigation water quality $\cdot$ Soil and crop hazards

\section{Introduction}

In recent years, following the imperative for "clean, green, and low-carbon" energy revolution (Huang et al. 2017), China has introduced policies to vigorously integrate coal

Qiyan Feng

fqycumt@126.com

1 School of Environment Science and Spatial Informatics, China University of Mining andTechnology, Xuzhou 221116, China

2 Low Carbon Energy Institute, China University of Mining and Technology, Xuzhou 221116, China resources and seal highly polluted, extensive, and poorly maintained mines (Xie et al. 2017). These closures have been accompanied by the development of environmental and geological disasters, impacting a large area. The concealment of the mines and their long incubation period are causing serious damage to sustainable development and the national economy. This paper studies the impact of mine water on surface water following the closure of a coal mine in Yudong River mining area of Kaili City, Guizhou Province.

The large-scale exploitation of coal resources in Yudong River area began in the early 1980s. The Permian Liangshan Formation of the regional coal-bearing strata features a coal seam with a thickness of $0.6-1.3 \mathrm{~m}$ and a dip angle 
of less than $10^{\circ}$. The methods used in coal mines are based on inclined and flat wells. More than 80 recorded coal mines have been worked in Yudong River area. Most have been closed, and only a few remained and are integrated. Production has been stopped at all mines. In the study area, 16 coal mines were merged and reorganized, and 26 privately owned mines were closed by the government or were closed on their own. Further, 16 unnamed small kilns remain; most are privately owned, small-scale, and have henhouse-like structures that have been abandoned for a long time. Coal mines are associated with large amounts of pyrite $\left(\mathrm{FeS}_{2}\right)$, which, after mine closure, becomes exposed to air or immersed in oxygen-rich water, forming acidic mine water with sulfate-rich ions and severely low local $\mathrm{pH}$ values ( $\mathrm{pH}$ up to 2 ), producing a series of oxidation reactions (Masindi et al. 2016). The pyrite reacts with $\mathrm{H}_{2} \mathrm{O}$ and $\mathrm{O}_{2}$, releasing $\mathrm{H}^{+}$and $\mathrm{Fe}^{2+}$, and the $\mathrm{Fe}^{2+}$ is converted into $\mathrm{Fe}^{3+}$ by $\mathrm{O}_{2}$ oxidation. As the $\mathrm{pH}$ values decrease, $\mathrm{Fe}^{3+}$ activity increases and further acts on pyrite as below(Nordstrom 2015; Masindi 2016):

$$
\begin{aligned}
& 2 \mathrm{FeS}_{2}(\mathrm{~s})+2 \mathrm{H}_{2} \mathrm{O}(\mathrm{l})+7 \mathrm{O}_{2}(\mathrm{~g}) \\
& \quad \rightarrow 2 \mathrm{Fe}^{2+}(\mathrm{aq})+4 \mathrm{SO}_{4}^{2-}(\mathrm{aq})+4 \mathrm{H}^{+}(\mathrm{aq}) \\
& 2 \mathrm{Fe}^{2+}(\mathrm{aq})+4 \mathrm{H}^{+}(\mathrm{aq})+2 \mathrm{O}_{2}(\mathrm{~g}) \\
& \quad \rightarrow 2 \mathrm{Fe}^{3+}(\mathrm{aq})+2 \mathrm{H}_{2} \mathrm{O} \\
& \mathrm{FeS}_{2}(\mathrm{~s})+14 \mathrm{Fe}^{3+}(\mathrm{aq})+8 \mathrm{H}_{2} \mathrm{O}(\mathrm{l}) \\
& \quad \rightarrow 15 \mathrm{Fe}^{2+}(\mathrm{aq})+2 \mathrm{SO}_{4}^{2-}(\mathrm{aq})+16 \mathrm{H}^{+}(\mathrm{aq})
\end{aligned}
$$

The ferrous ions are then oxidized and hydrolyzed to precipitate ochre, which can flood the riverbed and destroy benthic animals and plants as below (Francisco M. BaenaMoreno et al. 2020):

$$
\begin{gathered}
4 \mathrm{Fe}^{2+}(\mathrm{aq})+10 \mathrm{H}_{2} \mathrm{O}(\mathrm{l})+\mathrm{O}_{2}(\mathrm{~g}) \\
\rightarrow 4 \mathrm{Fe}(\mathrm{OH})_{3}(\mathrm{~s})+8 \mathrm{H}^{+}(\mathrm{aq})
\end{gathered}
$$

Acidic mine water is widely distributed and pollutes the immediate environment, threatening human safety and health (Park et al. 2019). The research area of this study falls in the area of Yudong River, a tributary of Chongan River in the upper reaches of Qingshui River in Yangtze River Basin. There are five drinking water reservoirs and 58 coal mines in the upper reaches of the river. From July 2017 to August 2018, eight mine water samples and eight river water samples were collected to measure various water quality indicators. The main objectives of this study are as follows: analyzing the physical and chemical properties and their seasonal changes in the mine water from 2017 to 2018; determining the seasonal and spatial variation in river water quality; evaluating the physical and chemical effects of mine water on river water quality after mine closure; and evaluating the feasibility and environmental impact of irrigation using river water.

\section{Materials and methods}

\subsection{Study area}

Yudong River originates in Dapo, Lushan, Kaili, and it mainly includes Baishui River (main trunk) and Pinglu River (tributary). After its confluence to make Chahe River, it flows into Wangjiatun, Wanshui, Kaili, and it enters into Chongan River. The landform has a middle and low mountain topography with erosion and corrosion. The interior is mostly a basin with a gentle slope, and a karst landform is presented. The terrain is generally high in the southeast and low in the northwest, featuring a low gully in the middle. Its highest point is $1230 \mathrm{~m}$ above sea level and $1200 \mathrm{~m}$ west of Shuishan, and the lowest point is at the estuary of Yudong River into Chong'an River. The mines polluting Yudong River Basin in the study area are mainly distributed across two areas. The first area is located in the area of Shangbao and Datian to Yanjiao (west of Lushan and Dafengdong), and the second area is concentrated in the middle and lower reaches of Baishui and Pinglu rivers.

The aquifers in the study area are mainly divided into four layers, according to their occurrence conditions, hydraulic characteristics, hydraulic properties, and geological groundwater structure (Fig. 1); these are a Cenozoic Quaternary sand gravel pore aquifer, a Permian Maokou Formation-Qixia Formation clastic limestone karst fissure aquifer, a Carboniferous Baizuo Formation dolomite karst

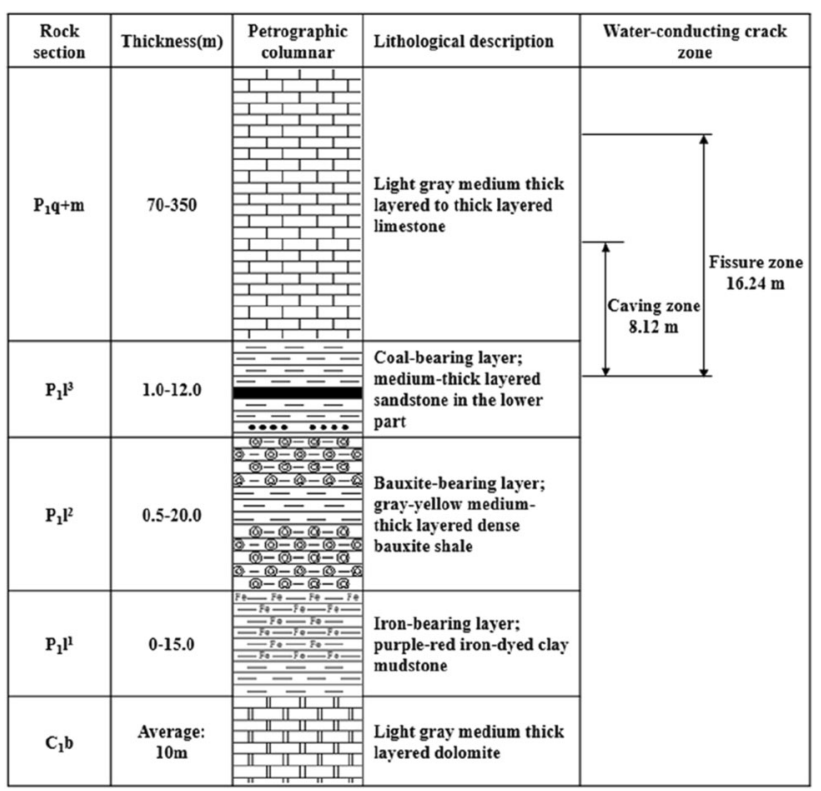

Fig. 1 Schematic diagram of the stratigraphic structure and the aquifer of the top and bottom plates of the Liangshan Formation $\left(\mathrm{P}_{1} \mathrm{q}\right.$, Qixia Formation; $\mathrm{P}_{1} 1$, Permian Lower Liangshan Formation; $\mathrm{C}_{1} \mathrm{~b}$, Carboniferous system Lower Liangshan Formation) 
fissure aquifer, and a Devonian Upper Yaosuo Formation bioclastic limestone karst fissure aquifer.

The average annual precipitation in the study area is $1264.7 \mathrm{~mm}$, and it is unevenly distributed, with a concentration from May to October. Atmospheric precipitation is the main source of groundwater recharge through surface infiltration. The topography determines the distribution of groundwater recharge and discharge areas, as well as the trend in groundwater flow. The surface karst depressions and falling water caves are of recent vintage and can directly accept atmospheric the precipitation infiltration recharge by injection, osmosis, and seepage. In addition, Pinglu and Baishui rivers are leaking through exposed areas in the Qixia-Maokou Formation limestone, replenishing the limestone aquifer of the Qixia Formation. The water runoff (pipe flow) is mainly caused by erosion and dissolution, and gap flows are formed by mutual communication among fractures, generally from south to north. The gap flows combine to form tube flows and an underground river, which is exposed in low-lying areas. As the groundwater collects, it flows into the northern Chongan River. The lowest erosion reference plane for the groundwater discharge in the area is Chongan River $(+582 \mathrm{~m})$, near the northern estuary. Most of the exposed and semi-exposed carbonate mountainous areas have developed surface karst, such as karst depressions, karst buckets, and other negative topography, which are supplied by infiltration of atmospheric precipitation. The karst water flows for a long distance before draining into the local river valley as a karst spring or underground river. The karst water in this area is characterized by point recharge, tubular runoff, and concentrated discharge.

A total of 21 drainage points were found in the study area, distributed across sections of three rivers: Baishui River, Pinglu River, and Jiangkou River (from Cha River to Chongan River). The preliminary statistics indicate that the total discharge is approximately $2660 \mathrm{~m}^{3} / \mathrm{h}$, the discharge of the drainage point of Baishui River is 630-865 $\mathrm{m}^{3} / \mathrm{h}$, Pinglu River's discharge reaches $1305 \mathrm{~m}^{3} / \mathrm{h}$, and Jiangkou River section has a concentrated discharge of approximately $200 \mathrm{~m}^{3} / \mathrm{h}$. The coal mine water mainly drains through wellbores (inclined wells and adits), karst caves, dark rivers, and karst fissure drainage points before flowing into the Yudong River. Among the 21 drainage points in the study area, there are 14 wellbore drainage points, five karst caves drainage points, three dark river drainage points, and two karst drainage points.

\subsection{Study methodology}

Eight mine water samples and eight river samples were collected in the study area. A map of the distribution of the sampling points is shown in Fig. 2. Each water sample was collected using a pre-cleaned $1.5 \mathrm{~L}$ polyethylene bottle. The $\mathrm{pH}$ was tested using a multi-function portable tester (Shanghai Raytheon PHS-25), and the samples were returned to the laboratory as quickly as possible. The water samples were then filtered in the laboratory using a 0.45 $\mu \mathrm{m}$ polyester fiber filter membrane and divided into two parts. For one part, $\mathrm{HNO}_{3}$ was used to adjust the $\mathrm{pH}$ value to be below 2 to determine the metal cation content through inductively coupled plasma mass spectrometry (ICP-MS). The other part remained acid free, and an ion chromatograph (IC) was used to determine anion content. The chemical oxygen demand (COD) was determined using the dichromate method (GB/T 11,914), and the total hardness was tested using the EDTA titration method.

\subsection{Standard limit}

The standard limit of mine water discharge is based on the relevant limits in the Coal Industry Pollutant Emission Standard (GB20426-2006) and the Guizhou Province Environmental Pollutant Emission Standard (DB 52/864-2013). According to the Water Function Zoning of Guizhou Province, Yudong River is part of the Chongan River Kaili Protection Area. Therefore, the applicable river water quality standard is the Class III water standard and centralized drinking water-supplementary project standards in surface water sources in the Surface Water Environmental Quality Standard (GB3838-2002). The irrigation water for farmland is referenced in the Water Quality Standard for Farmland Irrigation (GB5084-2021), and the limits for each evaluation standard are shown in Table 1.

\section{Results and discussion}

\subsection{Chemical analyses of mine water}

The Piper diagram of the mine water's chemical composition shows that $\mathrm{SO}_{4}{ }^{2-}$ is the main anion in the sample, and it is concentrated in the $\mathrm{Ca}, \mathrm{Fe}$, and Al fields (Fig. 3). Due to the natural conditions of the mine, the types of mineral resources, and the form of existence, the water type characteristics of different mine types also change (Feng et al. 2010). Among all water samples in the wet and dry seasons, the anions $\mathrm{Cl}^{-}, \mathrm{HCO}_{3}{ }^{-}, \mathrm{NO}_{2}{ }^{-}$, and $\mathrm{NO}_{3}{ }^{-}$have low concentrations, and high acidity is also not conducive to the stability of $\mathrm{HCO}_{3}{ }^{-}$. Therefore, the dominant aqueous phases of mine water in the study area are $\mathrm{Ca}-\mathrm{SO}_{4}, \mathrm{Fe}-$ $\mathrm{SO}_{4}$, and $\mathrm{Al}-\mathrm{SO}_{4}$. Conversely, the main mine water type suggests that the main pollutants in the mine water are $\mathrm{Fe}$, $\mathrm{Al}$, and $\mathrm{SO}_{4}{ }^{2-}$. 


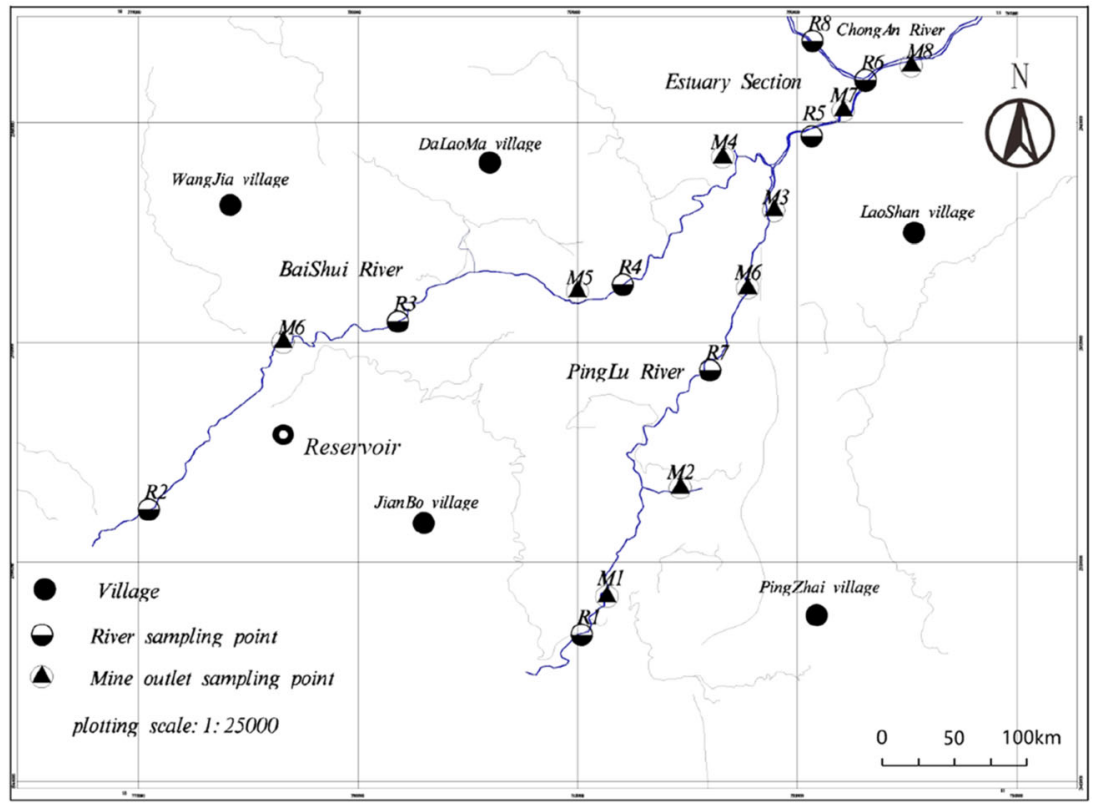

Fig. 2 Distribution map of sampling points

Table 1 Evaluation criteria limits

\begin{tabular}{|c|c|c|c|c|c|c|c|c|c|c|c|c|}
\hline Sample & $\mathrm{pH}$ & $\begin{array}{l}\mathrm{SO}_{4}{ }^{2-}(\mathrm{mg} / \\
\mathrm{L})\end{array}$ & $\begin{array}{l}\mathrm{Fe}(\mathrm{mg} / \\
\mathrm{L})\end{array}$ & $\begin{array}{l}\mathrm{Mn} \\
(\mathrm{mg} / \mathrm{L})\end{array}$ & $\begin{array}{l}\mathrm{Cu}(\mathrm{mg} / \\
\mathrm{L})\end{array}$ & $\begin{array}{l}\mathrm{Cd}(\mathrm{mg} / \\
\mathrm{L})\end{array}$ & $\begin{array}{l}\mathrm{Cr}(\mathrm{mg} / \\
\mathrm{L})\end{array}$ & $\begin{array}{l}\mathrm{Zn}(\mathrm{mg} / \\
\mathrm{L})\end{array}$ & $\begin{array}{l}\mathrm{F}(\mathrm{mg} / \\
\mathrm{L})\end{array}$ & $\begin{array}{l}\mathrm{Cl}(\mathrm{mg} / \\
\mathrm{L})\end{array}$ & $\begin{array}{l}\text { TDS } \\
(\mathrm{mg} / \mathrm{L})\end{array}$ & $\begin{array}{l}\mathrm{COD} \\
(\mathrm{mg} / \mathrm{L})\end{array}$ \\
\hline Mine water & $6-9$ & - & 1.0 & 4.0 & - & 0.1 & - & 2.0 & - & - & - & - \\
\hline $\begin{array}{l}\text { Surface } \\
\text { water }\end{array}$ & $6-9$ & 250 & 0.3 & 0.1 & 1.0 & 0.005 & 0.05 & 1.0 & 1.0 & 250 & - & 20 \\
\hline $\begin{array}{l}\text { Irrigation } \\
\text { water }\end{array}$ & $5.5-8.5$ & - & - & - & 0.5 & 0.01 & 0.1 & 2 & 2 & 350 & 1000 & 150 \\
\hline
\end{tabular}

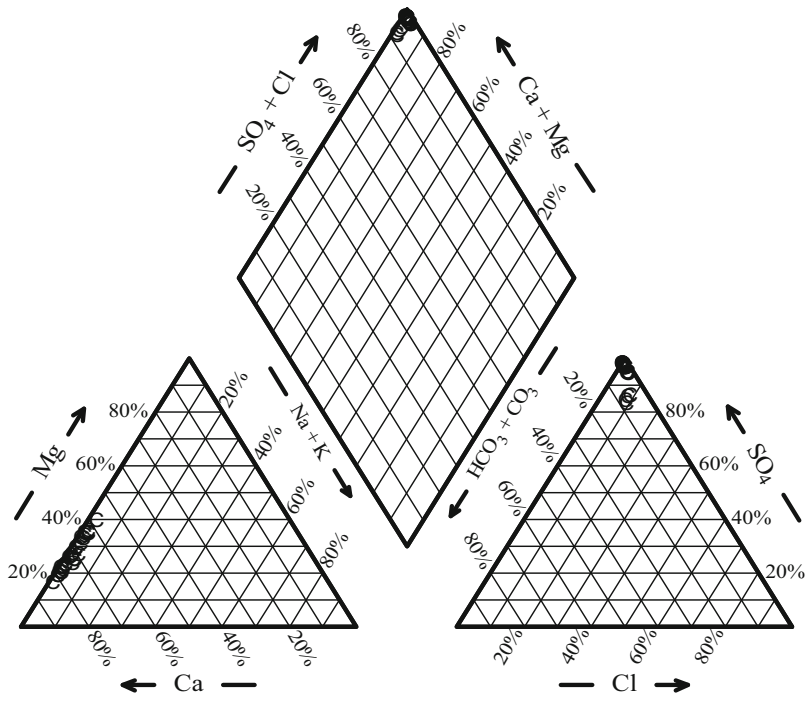

Fig. 3 Water chemistry characteristics of mine water
The water samples from the eight mines taken from July 2017 to August 2018 were statistically analyzed, and the results are shown in Table 2. The maximum and minimum values for $\mathrm{TH}, \mathrm{SO}_{4}{ }^{2-}, \mathrm{Fe}$, and $\mathrm{Al}$ differ by nearly 100 -fold, and the degree of data dispersion is high, indicating that mine water quality fluctuates greatly at different points. Most of the water quality indicators have a skew value greater than 0 , indicating positive skewness. The reason for this trend is that few variable values are excessively large, so the value on the right side of the mean is less than the value on the left, which indirectly reflects the large difference in the quality of the mine water (Atanackovic et al. 2013). The result of the kurtosis is similar to that for skewness and can reflect the distribution of random variables (Cain et al. 2017). The kurtosis values of different mine water parameters further indicate that the parameter of the water quality does not follow a normal distribution, and the water quality at different points is quite different (Đorić et al. 2009). The results of analyzing the Pearson correlation between different indicators show that $\mathrm{pH}$ and 
Table 2 Descriptive statistics of the mine water samples

\begin{tabular}{|c|c|c|c|c|c|c|c|c|c|c|}
\hline \multirow[t]{2}{*}{ Parameter } & \multicolumn{5}{|c|}{ July, 2017} & \multicolumn{5}{|c|}{ Dec, 2017} \\
\hline & Min. & Max. & Mean & Skewness & Kurtosis & Min. & Max. & Mean & Skewness & Kurtosis \\
\hline $\mathrm{pH}$ & 2.78 & 6.63 & 3.89 & 1.530 & 0.884 & 3.05 & 6.93 & 4.10 & 1.531 & 0.853 \\
\hline $\mathrm{COD}_{\mathrm{Cr}}(\mathrm{mg} / \mathrm{L})$ & 5 & 99 & 36 & 1.288 & 1.293 & 5 & 78 & 28 & 1.295 & 1.351 \\
\hline $\mathrm{TH}(\mathrm{mg} / \mathrm{L})$ & 139.046 & 1326.313 & 671.733 & 0.492 & -0.480 & 135.084 & 1208.407 & 637.496 & 0.399 & -0.689 \\
\hline $\mathrm{Fe}(\mathrm{mg} / \mathrm{L})$ & 9.14 & 752.95 & 287.70 & 0.834 & -0.117 & 6.34 & 714.52 & 258.37 & 0.964 & 0.201 \\
\hline $\mathrm{Ca}(\mathrm{mg} / \mathrm{L})$ & 72.940 & 269.253 & 196.982 & -1.013 & -0.060 & 68.346 & 238.849 & 175.132 & -0.980 & -0.190 \\
\hline $\mathrm{Al}(\mathrm{mg} / \mathrm{L})$ & 0.034 & 155.524 & 55.115 & 1.062 & 0.091 & 0.032 & 144.253 & 50.478 & 1.076 & 0.210 \\
\hline $\mathrm{Mg}(\mathrm{mg} / \mathrm{L})$ & 17.698 & 92.306 & 52.647 & 0.394 & -1.428 & 10.783 & 85.436 & 44.580 & 0.480 & -0.905 \\
\hline $\mathrm{K}(\mathrm{mg} / \mathrm{L})$ & 2.865 & 15.965 & 9.441 & 0.351 & -1.740 & 2.231 & 12.502 & 7.068 & 0.076 & -0.849 \\
\hline $\mathrm{Na}(\mathrm{mg} / \mathrm{L})$ & 0.554 & 3.517 & 1.771 & 0.519 & -0.115 & 0.578 & 2.816 & 1.398 & 0.808 & 0.520 \\
\hline $\operatorname{Mn}(\mathrm{mg} / \mathrm{L})$ & 0.136 & 2.510 & 1.467 & -0.578 & 0.353 & 0.119 & 2.038 & 1.171 & -0.582 & 0.982 \\
\hline $\mathrm{Sr}(\mathrm{mg} / \mathrm{L})$ & 0.1110 & 3.8760 & 1.4041 & 1.626 & 3.610 & 0.1005 & 3.6435 & 1.2857 & 1.736 & 3.995 \\
\hline $\mathrm{Zn}(\mathrm{mg} / \mathrm{L})$ & 0.049 & 1.473 & 0.732 & -0.014 & -0.969 & 0.063 & 1.056 & 0.616 & -0.225 & -1.969 \\
\hline $\mathrm{Ni}(\mathrm{mg} / \mathrm{L})$ & 0.0534 & 1.2250 & 0.5600 & 0.693 & 0.930 & 0.0501 & 1.1834 & 0.5174 & 0.885 & 1.402 \\
\hline Co $(\mathrm{mg} / \mathrm{L})$ & 0.0125 & 0.5127 & 0.2332 & 0.578 & 1.009 & 0.0097 & 0.4834 & 0.2111 & 0.764 & 1.373 \\
\hline $\mathrm{Li}(\mathrm{mg} / \mathrm{L})$ & 0.0244 & 0.2857 & 0.1225 & 1.098 & -0.336 & 0.0213 & 0.2609 & 0.1129 & 1.078 & -0.396 \\
\hline $\mathrm{Pb}(\mathrm{mg} / \mathrm{L})$ & 0 & 0.150 & 0.071 & -0.061 & -1.862 & 0.000 & 0.090 & 0.040 & 0.330 & -1.729 \\
\hline $\mathrm{Cr}(\mathrm{mg} / \mathrm{L})$ & 0 & 0.0975 & 0.0427 & 0.559 & -1.132 & 0.0089 & 0.0935 & 0.0408 & 0.753 & -1.074 \\
\hline $\mathrm{Be}(\mathrm{mg} / \mathrm{L})$ & 0.0008 & 0.0998 & 0.0371 & 0.899 & 0.066 & 0.0006 & 0.0912 & 0.0334 & 0.912 & -0.059 \\
\hline $\mathrm{Ba}(\mathrm{mg} / \mathrm{L})$ & 0.0142 & 0.0388 & 0.0237 & 1.010 & -0.044 & 0.0125 & 0.0375 & 0.0220 & 1.070 & 1.322 \\
\hline $\mathrm{Cd}(\mathrm{mg} / \mathrm{L})$ & 0 & 0.049 & 0.022 & 0.678 & 1.949 & 0 & 0.035 & 0.016 & 0.335 & 1.342 \\
\hline $\mathrm{Cu}(\mathrm{mg} / \mathrm{L})$ & 0 & 0.036 & 0.021 & -0.317 & -1.419 & 0 & 0.071 & 0.025 & 1.598 & 3.688 \\
\hline $\mathrm{Ti}(\mathrm{mg} / \mathrm{L})$ & 0.0070 & 0.0276 & 0.0171 & 0.266 & 0.167 & 0.0057 & 0.0252 & 0.0147 & 0.547 & 0.067 \\
\hline $\mathrm{SO}_{4}{ }^{2-}(\mathrm{mg} / \mathrm{L})$ & 221.846 & 2903.843 & 1363.788 & 0.768 & -0.173 & 198.547 & 2684.352 & 1201.760 & 0.923 & 0.511 \\
\hline $\mathrm{Cl}^{-}(\mathrm{mg} / \mathrm{L})$ & 7.09 & 19.50 & 14.84 & -1.033 & -0.392 & 6.07 & 17.46 & 12.36 & -0.570 & -1.263 \\
\hline $\mathrm{HCO}_{3}{ }^{-}(\mathrm{mg} / \mathrm{L})$ & 0 & 21.36 & 3.44 & 2.446 & 6.065 & 0 & 23.08 & 3.79 & 2.383 & 5.715 \\
\hline $\mathrm{NO}_{3}{ }^{-}(\mathrm{mg} / \mathrm{L})$ & 0 & 7.776 & 2.809 & 0.794 & -0.855 & 0.005 & 7.042 & 2.515 & 0.805 & -0.880 \\
\hline $\mathrm{F}^{-}(\mathrm{mg} / \mathrm{L})$ & 0.4 & 2.0 & 1.0 & 0.793 & -1.081 & 0.3 & 1.8 & 0.9 & 0.999 & -0.610 \\
\hline $\mathrm{NO}_{2}{ }^{-}(\mathrm{mg} / \mathrm{L})$ & 0 & 0.010 & 0.003 & 1.348 & 2.295 & 0 & 0.008 & 0.002 & 1.994 & 4.550 \\
\hline $\mathrm{S}^{2-}(\mathrm{mg} / \mathrm{L})$ & 0 & 0.009 & 0.003 & 0.664 & -2.156 & 0 & 0.008 & 0.003 & 0.670 & -2.131 \\
\hline \multirow[t]{2}{*}{ Parameter } & \multicolumn{5}{|c|}{ Mar, 2018} & \multicolumn{5}{|c|}{ Aug, 2018} \\
\hline & Min. & Max. & Mean & Skewness & Kurtosis & Min. & Max. & Mean & Skewness & Kurtosis \\
\hline $\mathrm{pH}$ & 2.98 & 6.78 & 4.10 & 1.455 & 0.463 & 2.51 & 6.52 & 3.81 & 1.438 & 0.735 \\
\hline $\mathrm{COD}_{\mathrm{Cr}}(\mathrm{mg} / \mathrm{L})$ & 5 & 99 & 36 & 1.288 & 1.293 & 5 & 99 & 36 & 1.288 & 1.293 \\
\hline $\mathrm{TH}(\mathrm{mg} / \mathrm{L})$ & 126.088 & 1225.646 & 624.645 & 0.425 & -0.386 & 135.504 & 1350.746 & 685.867 & 0.522 & -0.462 \\
\hline $\mathrm{Fe}(\mathrm{mg} / \mathrm{L})$ & 7.23 & 709.11 & 252.01 & 1.042 & 0.301 & 7.54 & 760.38 & 292.10 & 0.825 & -0.025 \\
\hline $\mathrm{Ca}(\mathrm{mg} / \mathrm{L})$ & 59.065 & 238.547 & 172.253 & -1.034 & -0.182 & 95.612 & 293.647 & 212.089 & -0.713 & 0.010 \\
\hline $\mathrm{Al}(\mathrm{mg} / \mathrm{L})$ & 0.029 & 138.073 & 48.670 & 1.059 & 0.200 & 0.035 & 164.209 & 56.928 & 1.117 & 0.305 \\
\hline $\mathrm{Mg}(\mathrm{mg} / \mathrm{L})$ & 13.640 & 78.061 & 40.902 & 0.604 & -0.974 & 16.549 & 108.351 & 61.642 & 0.286 & -1.452 \\
\hline $\mathrm{K}(\mathrm{mg} / \mathrm{L})$ & 1.852 & 11.059 & 6.357 & 0.136 & -0.657 & 4.210 & 19.067 & 11.056 & 0.685 & -0.823 \\
\hline $\mathrm{Na}(\mathrm{mg} / \mathrm{L})$ & 0.427 & 3.043 & 1.339 & 1.156 & 1.737 & 0.483 & 4.542 & 2.039 & 0.826 & 0.997 \\
\hline $\mathrm{Mn}(\mathrm{mg} / \mathrm{L})$ & 0.082 & 2.016 & 1.084 & -0.281 & 0.702 & 0.136 & 2.510 & 1.467 & -0.578 & 0.353 \\
\hline $\mathrm{Sr}(\mathrm{mg} / \mathrm{L})$ & 0.0837 & 3.3049 & 1.1526 & 1.824 & 4.440 & 0.1054 & 3.9463 & 1.4691 & 1.502 & 3.257 \\
\hline $\mathrm{Zn}(\mathrm{mg} / \mathrm{L})$ & 0.024 & 1.135 & 0.564 & -0.012 & -0.987 & 0.102 & 1.960 & 0.897 & 0.612 & -0.509 \\
\hline $\mathrm{Ni}(\mathrm{mg} / \mathrm{L})$ & 0.0461 & 1.0546 & 0.4845 & 0.674 & 0.886 & 0.0588 & 1.3376 & 0.5905 & 0.863 & 1.444 \\
\hline Co $(\mathrm{mg} / \mathrm{L})$ & 0.0083 & 0.4673 & 0.2020 & 0.789 & 1.449 & 0.0146 & 0.5629 & 0.2511 & 0.685 & 0.992 \\
\hline $\mathrm{Li}(\mathrm{mg} / \mathrm{L})$ & 0.0199 & 0.2496 & 0.1075 & 1.046 & -0.305 & 0.0296 & 0.3109 & 0.1337 & 1.140 & -0.263 \\
\hline
\end{tabular}


Table 2 continued

\begin{tabular}{|c|c|c|c|c|c|c|c|c|c|c|}
\hline \multirow[t]{2}{*}{ Parameter } & \multicolumn{5}{|c|}{ Mar, 2018} & \multicolumn{5}{|c|}{ Aug, 2018} \\
\hline & Min. & Max. & Mean & Skewness & Kurtosis & Min. & Max. & Mean & Skewness & Kurtosis \\
\hline $\mathrm{Pb}(\mathrm{mg} / \mathrm{L})$ & 0 & 0.120 & 0.059 & -0.127 & -1.565 & 0.000 & 0.210 & 0.111 & -0.169 & -1.421 \\
\hline $\mathrm{Cr}(\mathrm{mg} / \mathrm{L})$ & 0.0072 & 0.0896 & 0.0383 & 0.743 & -0.982 & 0.0095 & 0.1181 & 0.0488 & 0.912 & -0.336 \\
\hline $\mathrm{Be}(\mathrm{mg} / \mathrm{L})$ & 0.0008 & 0.0864 & 0.0316 & 0.909 & -0.013 & 0.0012 & 0.1132 & 0.0414 & 0.968 & 0.382 \\
\hline $\mathrm{Ba}(\mathrm{mg} / \mathrm{L})$ & 0.0107 & 0.0365 & 0.0211 & 0.910 & -0.064 & 0.0163 & 0.0422 & 0.0256 & 1.052 & -0.128 \\
\hline $\mathrm{Cd}(\mathrm{mg} / \mathrm{L})$ & 0 & 0.038 & 0.014 & 1.270 & 2.188 & 0.010 & 0.065 & 0.032 & 0.787 & -0.100 \\
\hline $\mathrm{Cu}(\mathrm{mg} / \mathrm{L})$ & 0 & 0.068 & 0.021 & 2.006 & 5.028 & 0.012 & 0.046 & 0.028 & 0.249 & -1.901 \\
\hline $\mathrm{Ti}(\mathrm{mg} / \mathrm{L})$ & 0.0046 & 0.0219 & 0.0124 & 0.742 & 0.170 & 0.0083 & 0.0251 & 0.0180 & -0.898 & 2.116 \\
\hline $\mathrm{SO}_{4}^{2-}(\mathrm{mg} / \mathrm{L})$ & 209.085 & 2486.348 & 1154.688 & 0.846 & 0.080 & 230.543 & 2835.497 & 1427.337 & 0.584 & -0.602 \\
\hline $\mathrm{Cl}^{-}(\mathrm{mg} / \mathrm{L})$ & 5.31 & 16.73 & 12.10 & -0.796 & -1.143 & 8.16 & 21.38 & 14.37 & 0.090 & -2.330 \\
\hline $\mathrm{HCO}_{3}{ }^{-}(\mathrm{mg} / \mathrm{L})$ & 0 & 24.91 & 4.07 & 2.403 & 5.827 & 0 & 18.36 & 3.03 & 2.369 & 5.641 \\
\hline $\mathrm{NO}_{3}{ }^{-}(\mathrm{mg} / \mathrm{L})$ & 0 & 6.587 & 2.403 & 0.764 & -0.960 & 0 & 8.057 & 3.053 & 0.680 & -1.058 \\
\hline $\mathrm{F}^{-}(\mathrm{mg} / \mathrm{L})$ & 0.3 & 1.6 & 0.8 & 0.793 & -1.171 & 0.5 & 2.2 & 1.2 & 0.764 & -0.953 \\
\hline $\mathrm{NO}_{2}^{-}(\mathrm{mg} / \mathrm{L})$ & 0 & 0.009 & 0.003 & 1.877 & 4.501 & 0.002 & 0.015 & 0.005 & 1.865 & 3.469 \\
\hline $\mathrm{S}^{2-}(\mathrm{mg} / \mathrm{L})$ & 0 & 0.008 & 0.003 & 0.736 & -1.894 & 0 & 0.010 & 0.005 & -0.444 & -2.090 \\
\hline
\end{tabular}

$\mathrm{HCO}_{3}{ }^{-}$are significantly correlated at a level of 0.01 , showing that the regional type of chemistry of the water is not likely to be an $\mathrm{HCO}_{3}$ type. The $\mathrm{pH}$ is negatively correlated with other metal ions. $\mathrm{SO}_{4}{ }^{2-}$ has a strong correlation with $\mathrm{Fe}, \mathrm{Al}$, and $\mathrm{Zn}$, surpassing the significance test at a confidence level of $99 \%$, which provides important evidence for the biological or chemical oxidation of the sulfide minerals (Mosley et al. 2018).

AMD typically has a low $\mathrm{pH}$ and a high concentration of dissolved metal ions and sulfates. This is largely due to the physical destruction of the coal and bedrock, which is often exposed to oxygen and water (Silva et al. 2012). Under the combined action of non-biological oxidation and bio-oxidation, the exposed sulfide minerals produce large amounts of $\mathrm{H}^{+}$and metal ions in mine water (Tolonen et al. 2014). Ullrich et al. analyzed the bacterial community of drainage sediments in the overflow area of abandoned coal mines and identified thiobacillus ferrooxidans such as Ferrovum, which can effectively convert insoluble metal oxides into dissolved metal ions (Ullrich et al. 2016; Brantner and Senko 2014).

Figure 4 shows the physicochemical properties of M3 sampling points in the wet and dry seasons in different years. The $\mathrm{pH}(3.07-3.25)$ and $\mathrm{Fe}(709.11-760.38 \mathrm{mg} / \mathrm{L})$ concentrations in the M3 sample obviously exceed the mine water discharge limit specified in the Coal Industry Pollutant Emission Standard (GB20426-2006). Moreover, the acidic water had a higher total hardness (1326.313-1208.407 mg/L) and sulfate concentration (2486.348-2903.843 mg/L). The water quality was better during the wet season (July 2017/August 2018) than the dry season (December 2017/March 2018). The main reason for this was that the rainfall supplemented the groundwater during the wet season, and a large amount of groundwater poured into the mouth of the mine, discharging a large amount of mine water in the process. In addition, during the dry season, the amount of water falls due to evaporation, and the solubility of the soluble salts is reduced for various metals such as $\mathrm{Fe}$ and $\mathrm{Al}$, resulting in improved water quality (Appelo and Postma 2005; Nordstorm and Alpers 1999). However, the fluctuation is small.

In the study area, 28 centralized stacking sites were seen for coal gangue, and no treatment measures were taken. According to the researches of He et al. (2018) and Zhao et al. (2016) on static and dynamic leaching of coal gangue, the leaching filtrate has a low $\mathrm{pH}$ and is characterized by the strong release of metal ions. These findings are consistent with the leaching results of this study (Table 3). According to the climatic conditions of Kaili, the leaching amount of coal gangue in the dry season is significantly lower than that in the wet season. In both the dry and wet seasons, the coal gangue leaching solution falls along with the surface runoff and diffuses contaminants such as $\mathrm{H}^{+}$, $\mathrm{Fe}, \mathrm{Cu}, \mathrm{Zn}$, and $\mathrm{Cd}$ into the water, thereby causing pollution of the surface water and groundwater. Compared to mine water, the quantity of coal gangue leaching water is small, but it is characterized by high acidity, high $\mathrm{Fe}$ and $\mathrm{Cd}$, and high pollution toxicity, greatly damaging local water, soil, vegetation, and crops (Rashed 2010).

The water sources that are filled with mine water in the study area are mainly derived from atmospheric precipitation, groundwater, and goaf water accumulation (Fan et al. 2019; Yu et al. 2020). Atmospheric precipitation is the main source of groundwater supply in the mining area. 


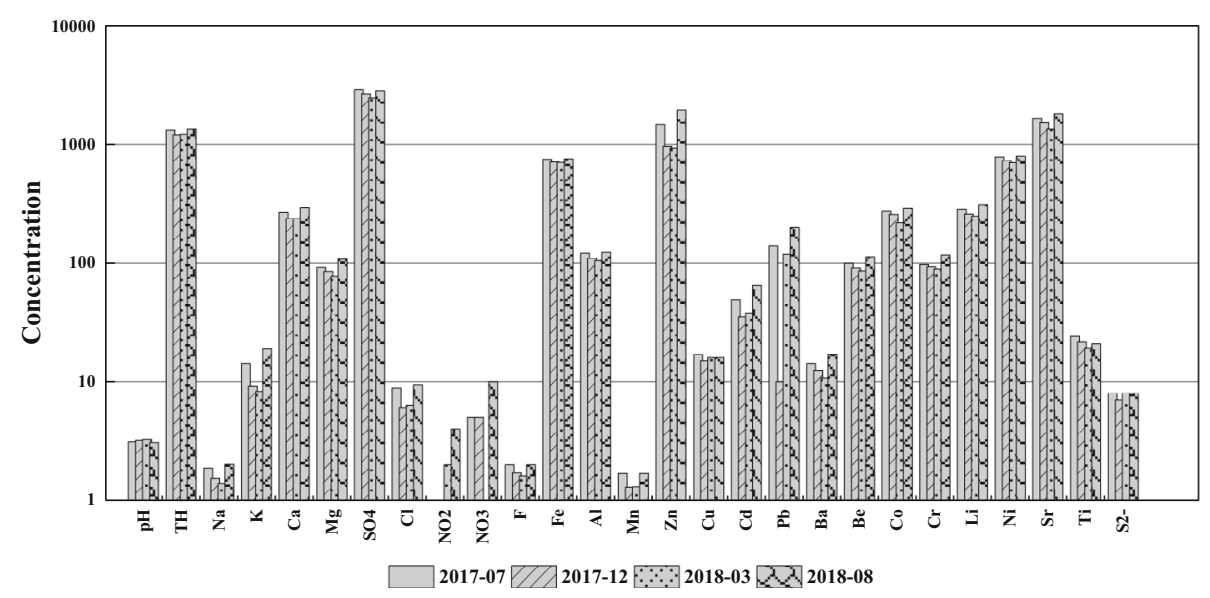

Fig. 4 Water quality results of mine water (M3 sampling point) during the wet season and dry season in 2017 and 2018; Among them, TH, Na, $\mathrm{K}, \mathrm{Ca}, \mathrm{Mg}, \mathrm{SO}_{4}{ }^{2-}, \mathrm{Cl}^{-}, \mathrm{F}^{-}, \mathrm{Fe}, \mathrm{Al}$ and $\mathrm{Mn}, \mathrm{mg} / \mathrm{L}: \mathrm{NO}_{2}{ }^{-}, \mathrm{NO}_{3}{ }^{-}, \mathrm{Zn}, \mathrm{Cu}, \mathrm{Cd}, \mathrm{Pb}, \mathrm{Ba}, \mathrm{Be}, \mathrm{Co}, \mathrm{Cr}, \mathrm{Li}, \mathrm{Ni}, \mathrm{Sr}, \mathrm{Ti}$ and $\mathrm{S}^{2-}, \mu \mathrm{g} / \mathrm{L}$

Table 3 Results of coal gangue leaching water quality

\begin{tabular}{lllllll}
\hline Sample & $\mathrm{pH}$ & $\mathrm{Fe}(\mathrm{mg} / \mathrm{L})$ & $\mathrm{Mn}(\mathrm{mg} / \mathrm{L})$ & $\mathrm{Cu}(\mathrm{mg} / \mathrm{L})$ & $\mathrm{Zn}(\mathrm{mg} / \mathrm{L})$ & $\mathrm{Cd}(\mathrm{mg} / \mathrm{L})$ \\
\hline $\mathrm{G} 1$ & 3.06 & 422 & 1.56 & 0.350 & 1.10 & 8.88 \\
$\mathrm{G} 2$ & 3.03 & 388 & 2.72 & 0.068 & 1.02 & 3.68 \\
\hline
\end{tabular}

However, because the top and bottom of the mine have a certain water-blocking effect, the groundwater can only increase during the large summer rainfalls. The groundwater mainly comes from the bedrock fissure water and karst fissure water overlying or underlying coal seams. The cracks caused by the coal mining is infiltrated, dripped, drenched into the mining roadway, or poured into the roadway in the form of water inrush, thus becoming a direct water-filling water source. The mine water in the study area is mainly discharged from wellheads such as abandoned adits, wind shafts, and inclined shafts, which are the primary sources of pollution inputs to Yudong River. In the early stages of Yudong River area, there was abandoned coal mines, and more goafs were formed. When the atmospheric precipitation infiltrates into the goaf and the water level is higher than the well elevation, the groundwater flows out along the wellbore and become the main channel of the discharged mine water.

\subsection{Irrigation water quality}

An analysis of the water type in Yudong River is shown in Fig. 5. Compared to the constituents of the water chemistry in mine water, $\mathrm{SO}_{4}{ }^{2-}$ and $\mathrm{HCO}_{3}{ }^{-}$are the main anions in river water samples and are concentrated in the $\mathrm{Ca}$ and $\mathrm{Fe}$ fields (Selvakumar et al. 2017). Therefore, the dominant aqueous phases of the river water in the study area are $\mathrm{Ca}$ $\mathrm{SO}_{4}$ and $\mathrm{Ca}-\mathrm{HCO}_{3}$. The mine water was found to have a higher degree of mineralization than the river water and to contain more soluble solid materials. The high contents of $\mathrm{Fe}$ and $\mathrm{Al}$ in the mine water had an impact on the type of water chemistry type.

From 2017-2018, the water quality of eight river samples was measured (Fig. 6). According to the Class III water standard and centralized drinking water-supplementary project standards for surface water sources in the Surface Water Environmental Quality Standard (GB3838-2002), the only uncontaminated sample of the eight samples was R1. R1 is located at the mouth of the river, and there are no mines around; therefore, this sample can also be used as the initial baseline value for the river. At R2 and R8, Fe exceeds the standard. At R3, Mn exceeds the standard. At R4, sulfates and Mn exceed the standard. At R5 and R6, the pH, Fe, sulfate, $\mathrm{Mn}$, and $\mathrm{Cd}$ all exceed the limit value. R7 is in a tributary of Pinglu River, and R2, $\mathrm{R} 3$, and R4 are in tributaries of Baishui River. The discharge points of the mines are scattered along the tributaries, and there is a great distance between the mines. The river displays notable confluence, dilution, and degradation effects. These processes make the samples less polluted, and only a few indicators exceed the limit. R8 is located on Chongan River. The large gap between the water quantities of Chongan River and Yudong River alleviates the amount the exceeded standard. R5 and R6 are located at the confluence of Pinglu River and Baishui River. Although they receive pollutants from each tributary, the mine drainage is 


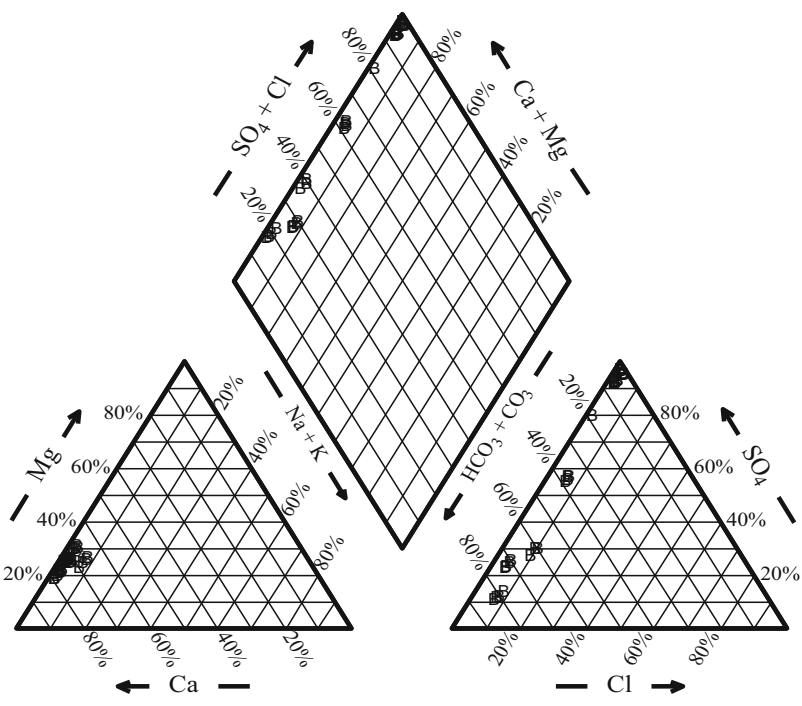

Fig. 5 Water chemistry characteristics of Yudong River

concentrated at the confluence, as the areas include Qiaotou mine, Banpo mine, Jiangkou mine, and other large mines. Mine water drains at this stage, and the superposition and accumulation of the two parts cause the river to seriously exceed the standard. Compared to that at R1, the $\mathrm{Fe}$ content in the R5 section increased by $128.5 \mathrm{mg} / \mathrm{L}$, and $\mathrm{SO}_{4}{ }^{2-}$ increased by $672.4 \mathrm{mg} / \mathrm{L}$. The water quality in the dry season is better than that in the flood season, and the quality of the river water quality gradually worsens. For example, the sulfate content at R6 decreased by $39 \mathrm{mg} / \mathrm{L}$ in the dry season compared to the value in the wet season, the Fe content decreased by $16 \mathrm{mg} / \mathrm{L}$, the $\mathrm{F}^{-}$content decreased by $67 \%$, and the $\mathrm{Cd}$ content was halved. Under normal circumstances, large precipitation occurs during the wet season, and the water pollution is diluted (Acikel and Ekmekci 2018). However, in Yudong River area, the main factors limiting the quality of river water are mine water drainage and low-quality inflows. During the flood season, the mine hole in Yudong River area features a large drainage and poor water quality, and the amount of coal gangue leaching water quantity increases, resulting in more serious pollution across all sections during the wet season (Wang et al. 2013).

Evaluations of water quality are important for characterizing the suitability of water for any purpose. According to the Water Quality Standard for Farmland Irrigation (GB5084-2021), the water quality parameters $\mathrm{pH}$ value and Cd content of R5 and R6 exceed standard water quality values. The $\mathrm{pH}$ value at $\mathrm{R} 5$ and $\mathrm{R} 6$ is consistently lower than the irrigation standard $(\mathrm{pH}=5.5-8.5)$, and in the wet season, the $\mathrm{pH}$ value at $\mathrm{R} 4$ and $\mathrm{R} 5$ is even lower than 4.8. Most agricultural products and plants, such as mung bean, red bean, eucalyptus, and milk vetch, tolerate soil acidity levels between 6.5 and 7.5 (Yuan and $\mathrm{Xu}$
2012). When the acidity is high, $\mathrm{H}^{+}$will compete with various cations (such as $\mathrm{Ca}^{2+}$ ) at the protoplasmic membrane of the cell, resulting in enhanced cell membrane permeability and inhibiting the selective permeability of the cell membrane to nutrients ( $\mathrm{Yu}$ 2018). $\mathrm{H}^{+}$also causes inactivation of the plant enzyme system, limits respiration, directly harms plant roots, inhibits plant growth, and even causes plant death ( $\mathrm{Li}$ et al. 2019). Use of this section of river water may break the original buffer system of the soil and intensify soil acidity.

Regarding Cd content, R5 and R6 exceeded the irrigation limit value of $0.01 \mathrm{mg} / \mathrm{L}$ in both the wet and dry seasons. In fact, according to the Toxic Substances and Disease Registry (ATSDR Substance Priority List 2019), $\mathrm{Cd}$ is among the top ten priority substances to monitor. $\mathrm{Cd}$ is highly toxic and has a half-life of 10-30 years in the human body; thus, it degrades only slowly. Cd may even cause renal failure, diabetes, osteoporosis, and other issues (Rahimzadeh et al. 2017). The main sources of carbohydrates are currently wheat and rice, which are highly enriched crops. If excessive water is used for irrigation, it may directly affect human health (Zhu et al. 2016; Nisarat et al. 2015).

Apart from Cd, R5 and R6, other parameters, such as Fe, $\mathrm{Al}$, and sulfate, are not referenced in the irrigation standards, but as the main pollutants in mine water, they are found in high concentrations in river water. For example, $\mathrm{Fe}^{2+}$ is oxidized and hydrolyzed, forming $\mathrm{Fe}(\mathrm{OH})_{3}$, which floods the riverbed or covers the surfaces of water bodies, resulting in the death of most aquatic organisms, such as algae and benthic plants (Eduardo et al. 2013). As highconcentration river water is irrigated into the surrounding farmland system, the plant roots absorb Fe, affecting their normal growth (Digesti and Weeth 1976). In general, sulphate is non-toxic, but when it is ingested in large quantities, it can cause diarrhea, dehydration, and changes in methemoglobin and sulfur hemoglobin levels in humans and animals (Gomez et al. 1995). Due to osmotic regulating pressure, some freshwater species are directly killed by excessive sulphate concentrations (Soucek and Kennedy 2005). In addition, when farmland is irrigated with highacidity water, the concentration of $\mathrm{Al}$ in the soil solution increases, which directly inhibits the absorption of water and nutrients by the plant roots, reduces the chlorophyll content of plants, and affects plant photosynthesis (Exley 2012). Furthermore, during irrigation process, plants are prone to bivalent manganese poisoning. Because the manganese content is too high, it inhibits the activities of enzymes such as cytochrome oxidase, ascorbate oxidase, and nitrate reductase, interfering with the normal activity of the enzyme system in plant cells and inhibiting physiological and biochemical processes such as photosynthesis (Larseen and Garmichad 2000). By analyzing the 

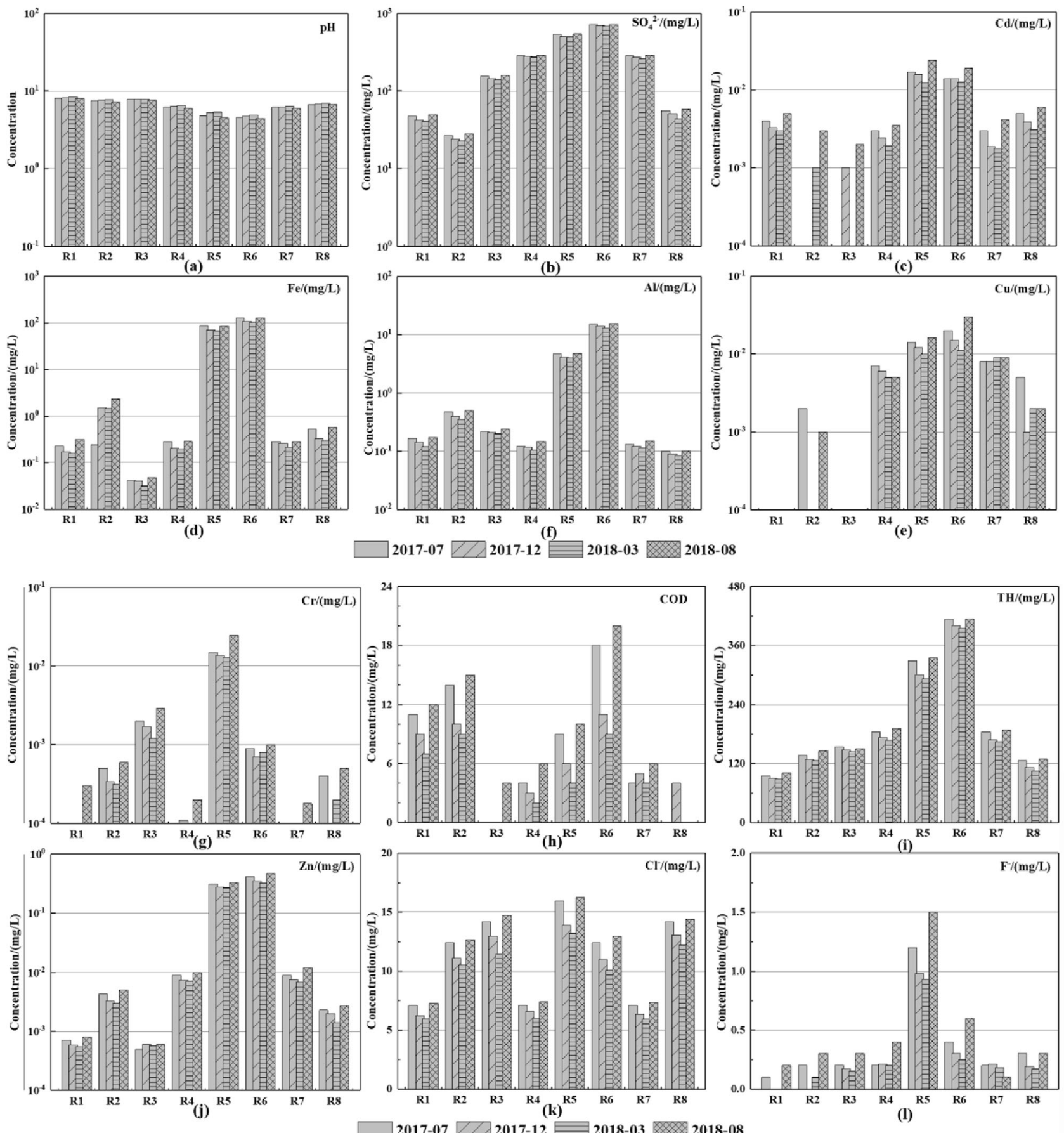

Fig. 6 Changes in water quality of the samples of Yudong River during the wet season and dry season in 2017 and 2018

correlation between physical and chemical properties of river water (Table 4), the results show that $\mathrm{pH}$ and metal ions are significantly correlated at the 0.05 level, and both are negatively correlated. In other words, the increase in water acidity accelerates the deterioration of water quality.

The sampling results for acid mine water at M3 and river water from July 2017 to Aug. 2018 (to assess the correlation between mine water and river water in a relatively short period of time) are shown in Table 5. It should be noted that the constituents of the polluted river water are mostly consistent with the main pollutants in the acid mine water, such as $\mathrm{Fe}, \mathrm{Al}, \mathrm{SO}_{4}{ }^{2-}, \mathrm{F}^{-}, \mathrm{Cd}$, and so forth, and the overall trends in time and space are consistent. This is mainly because the mine drainage is the main cause of river pollution. For example, at the confluence of Pinglu River tributary and Baishui River, the main coal 
Table 4 Correlation between the $\mathrm{pH}$ and chemical parameters of samples $(p<0.05)$

\begin{tabular}{|c|c|c|c|c|c|}
\hline Chemical parameter & $\mathrm{Ca}$ & $\mathrm{Mg}$ & $\mathrm{SO}_{4}{ }^{2-}$ & $\mathrm{F}^{-}$ & $\mathrm{Fe}$ \\
\hline $\mathrm{pH}$ value & -0.916 & -0.909 & -0.917 & -0.729 & -0.832 \\
\hline Chemical parameter & $\mathrm{Al}$ & $\mathrm{Mn}$ & $\mathrm{Zn}$ & $\mathrm{Cu}$ & $\mathrm{Cd}$ \\
\hline $\mathrm{pH}$ value & -0.732 & -0.934 & -0.849 & -0.974 & -0.857 \\
\hline
\end{tabular}

mines in the surrounding area are Qiaotou mine, Jiangkou mine, and Banpo mine. The water drainage from these three mines during the wet season reached 290, 214.76, and $711.52 \mathrm{~m}^{3} / \mathrm{h}$, respectively. The lowest water drainages at these mines during the dry season were $22.7,18$, and 45.5 $\mathrm{m}^{3} / \mathrm{h}$, respectively. Mine drainage is affected by the seasons, and drainage during the wet season is about 13 times more than that during the dry season, which also affects the water quality of the river in different seasons.

In villages around the Yudong River area, irrigating farmland with surface water from the tributary confluence during the summer may pose a significant risk to soil and crops. Using this type of water for irrigation will not only lead to soil degradation but may also hinder soil growth and plant metabolic activities, and could even cause toxic elements such as $\mathrm{Cd}, \mathrm{Fe}, \mathrm{Mn}, \mathrm{SO}_{4}{ }^{2-}, \mathrm{Al}$, and $\mathrm{F}^{-}$to enter the food chain, thereby jeopardizing human health (Ogunlaja et al. 2019). Currently, Kaili has built three coal mine wastewater treatment stations for the three large mine water outlets in the Yudong River Basin, which are at Yudong Coal Mine, Pingluhe Coal Mine, and Wuliqiao Coal Mine. To increase the $\mathrm{pH}$ of the mine water and reduce the concentration of pollutants ( $\mathrm{Fe}$ and $\mathrm{Mn}$ ), the treatment stations implemented the process of neutralization combined with aeration and filtration, but the treatment volume was insufficient and the sludge treatment volume was large.

\section{Conclusions}

There are many goaves in Yudong River area. After most of the mines closed in 2017, atmospheric precipitation still infiltrated them. When the water level exceeds the wellbore level, the mine water flows out along the wellbores and becomes the main source of pollution in Yudong River. This study shows that in the study area, even after the mines were closed, the pollution of Yudong River from mine water persisted. By analyzing the water pollution components of mines at different points and periods, the results showed that the main pollutants of mine water are $\mathrm{pH}, \mathrm{Fe}, \mathrm{Al}, \mathrm{Mn}, \mathrm{Cd}, \mathrm{F}$, and $\mathrm{SO}_{4}{ }^{2-}$, exceeding the standard limit values. The most polluted section of Yudong River is concentrated where Baishui River and Pinglu River converge. After Yudong River merges into Chongan River, most water quality indicators meet water quality standards due to dilution, but $\mathrm{Fe}$ and $\mathrm{Cd}$ still exceed the standards. During the wet season, mine water and surface water pollution are the heaviest, and the water quality continues to decline over time. The low $\mathrm{pH}$, high $\mathrm{Cd}$ levels (exceeding the standard limit for irrigation water) and high $\mathrm{Fe}, \mathrm{SO}_{4}{ }^{2-}$, and TDS contents (not included in the irrigation standard) indicate that the water quality problem in the study area is serious. When used for irrigating farmland, the water requires special care, and the long-term use of this water not only pollute the surrounding soil and crops but also endanger human health. 
Table 5 Chemical composition of mine water (M3) and river water (Ri) in the Yudong River area from July, 2017 to Aug, 2018

\begin{tabular}{|c|c|c|c|c|c|c|c|c|c|}
\hline Sample & Time & $\mathrm{pH}$ & $\mathrm{COD}_{\mathrm{Cr}}(\mathrm{mg} / \mathrm{L})$ & Hardness & $\mathrm{Ca}(\mathrm{mg} / \mathrm{L})$ & $\mathrm{Mg}(\mathrm{mg} / \mathrm{L})$ & $\mathrm{HCO}_{3}{ }^{-}$ & $(\mathrm{mg} / \mathrm{L})$ & $\mathrm{SO}_{4}{ }^{2-}(\mathrm{mg} / \mathrm{L})$ \\
\hline \multirow[t]{4}{*}{ M3 } & 2017.07 & 3.12 & 99 & 1326.313 & 269.253 & 92.306 & 0 & & 2903.843 \\
\hline & 2017.12 & 3.20 & 78 & 1208.407 & 238.849 & 85.436 & 0 & & 2684.352 \\
\hline & 2018.03 & 3.25 & 99 & 1225.646 & 238.547 & 78.061 & 0 & & 2486.348 \\
\hline & 2018.08 & 3.07 & 99 & 1350.746 & 293.647 & 108.351 & 0 & & 2835.497 \\
\hline \multirow[t]{4}{*}{$\mathrm{R} 1$} & 2017.07 & 8.16 & 11 & 95.087 & 54.247 & 13.305 & 164.75 & & 47.354 \\
\hline & 2017.12 & 8.21 & 9 & 90.015 & 52.257 & 11.964 & 159.02 & & 42.357 \\
\hline & 2018.03 & 8.37 & 7 & 88.997 & 50.455 & 10.536 & 157.15 & & 41.005 \\
\hline & 2018.08 & 8.06 & 12 & 100.625 & 59.425 & 15.479 & 167.27 & & 49.626 \\
\hline \multirow[t]{4}{*}{$\mathrm{R} 4$} & 2017.07 & 6.23 & 4 & 184.351 & 111.078 & 19.908 & 36.61 & & 285.923 \\
\hline & 2017.12 & 6.30 & 3 & 172.930 & 90.026 & 20.002 & 30.58 & & 279.653 \\
\hline & 2018.03 & 6.51 & 2 & 167.052 & 88.358 & 19.010 & 28.45 & & 274.543 \\
\hline & 2018.08 & 6.02 & 6 & 190.753 & 120.567 & 21.013 & 38.03 & & 289.213 \\
\hline \multirow[t]{4}{*}{ R5 } & 2017.07 & 4.78 & 9 & 329.322 & 142.909 & 31.046 & 6.10 & & 538.000 \\
\hline & 2017.12 & 5.22 & 6 & 301.246 & 129.988 & 29.353 & 5.52 & & 502.170 \\
\hline & 2018.03 & 5.38 & 4 & 292.986 & 124.257 & 27.867 & 5.01 & & 499.010 \\
\hline & 2018.08 & 4.52 & 10 & 335.458 & 149.225 & 34.596 & 6.70 & & 541.235 \\
\hline \multirow[t]{4}{*}{ R6 } & 2017.07 & 4.53 & 18 & 413.638 & 162.630 & 35.856 & 0 & & 713.308 \\
\hline & 2017.12 & 4.75 & 11 & 400.543 & 149.259 & 33.203 & 0 & & 699.320 \\
\hline & 2018.03 & 4.88 & 9 & 395.782 & 144.698 & 31.135 & 0 & & 687.960 \\
\hline & 2018.08 & 4.41 & 20 & 415.015 & 167.154 & 38.872 & 0 & & 719.753 \\
\hline \multirow[t]{4}{*}{ R7 } & 2017.07 & 6.23 & 4 & 184.351 & 111.078 & 19.908 & 36.61 & & 285.923 \\
\hline & 2017.12 & 6.21 & 5 & 168.453 & 99.258 & 18.875 & 34.87 & & 270.901 \\
\hline & 2018.03 & 6.37 & 4 & 164.024 & 95.961 & 17.200 & 32.47 & & 258.970 \\
\hline & 2018.08 & 6.01 & 6 & 188.586 & 117.534 & 20.905 & 37.12 & & 288.976 \\
\hline \multirow[t]{4}{*}{$\mathrm{R} 8$} & 2017.07 & 6.68 & 0 & 125.765 & 69.739 & 19.561 & 195.26 & & 55.846 \\
\hline & 2017.12 & 6.83 & 0 & 111.981 & 60.987 & 17.997 & 186.39 & & 50.987 \\
\hline & 2018.03 & 6.92 & 0 & 105.287 & 57.457 & 15.980 & 184.67 & & 43.802 \\
\hline & 2018.08 & 6.74 & 0 & 129.204 & 73.584 & 21.235 & 198.13 & & 57.965 \\
\hline Sample & $\mathrm{Cl}^{-}(\mathrm{mg} / \mathrm{L})$ & $\mathrm{F}^{-}(\mathrm{mg} / \mathrm{L}$ & $\mathrm{Fe}(\mathrm{mg} / \mathrm{L})$ & $\mathrm{Al}(\mathrm{mg} / \mathrm{L})$ & $\mathrm{Mn}(\mathrm{mg} / \mathrm{L})$ & $\mathrm{Zn}(\mathrm{mg} / \mathrm{L})$ & $\mathrm{Cu}(\mathrm{mg} / \mathrm{L})$ & $\mathrm{Cd}(\mathrm{mg} / \mathrm{L})$ & $\mathrm{Cr}(\mathrm{mg} / \mathrm{L})$ \\
\hline \multirow[t]{4}{*}{ M3 } & 8.86 & 2.0 & 752.95 & 122.135 & 1.683 & 1.473 & 0.017 & 0.049 & 0.0975 \\
\hline & 6.07 & 1.7 & 714.52 & 109.847 & 1.297 & 0.963 & 0.015 & 0.035 & 0.0935 \\
\hline & 6.34 & 1.6 & 709.11 & 105.243 & 1.305 & 0.931 & 0.016 & 0.038 & 0.0896 \\
\hline & 9.42 & 2.0 & 760.38 & 124.073 & 1.683 & 1.960 & 0.016 & 0.065 & 0.1181 \\
\hline \multirow[t]{4}{*}{ R1 } & 7.09 & 0 & 0.228 & 0.1677 & 0.0109 & 0.0007 & 0 & 0.004 & 0.0000 \\
\hline & 6.23 & 0 & 0.172 & 0.1425 & 0.0107 & 0.0006 & 0 & 0.003 & 0.0001 \\
\hline & 5.98 & 0 & 0.160 & 0.1196 & 0.0101 & 0.0006 & 0 & 0.003 & 0 \\
\hline & 7.27 & 0 & 0.241 & 0.1721 & 0.0130 & 0.0008 & 0 & 0.005 & 0.0003 \\
\hline \multirow[t]{4}{*}{$\mathrm{R} 4$} & 7.09 & 0.2 & 0.288 & 0 & 0.4709 & 0.0090 & 0.007 & 0.003 & 0.0001 \\
\hline & 6.57 & 0.2 & 0.201 & 0 & 0.4698 & 0.0074 & 0.006 & 0.002 & 0.0001 \\
\hline & 6.01 & 0.2 & 0.200 & 0 & 0.4503 & 0.0071 & 0.005 & 0.002 & 0.0001 \\
\hline & 7.40 & 0.4 & 0.290 & 0 & 0.4821 & 0.0100 & 0.005 & 0.004 & 0.0002 \\
\hline \multirow[t]{4}{*}{ R5 } & 15.95 & 1.2 & 85.934 & 4.6440 & 0.8647 & 0.3098 & 0.014 & 0.017 & 0.0150 \\
\hline & 13.89 & 1.0 & 69.660 & 4.0270 & 0.7526 & 0.2754 & 0.012 & 0.016 & 0.0137 \\
\hline & 13.21 & 0.9 & 67.255 & 3.9850 & 0.7124 & 0.2699 & 0.010 & 0.012 & 0.0129 \\
\hline & 16.24 & 1.5 & 85.215 & 4.7635 & 0.8900 & 0.3305 & 0.016 & 0.024 & 0.0245 \\
\hline
\end{tabular}


Table 5 continued

\begin{tabular}{|c|c|c|c|c|c|c|c|c|c|}
\hline Sample & $\mathrm{Cl}^{-}(\mathrm{mg} / \mathrm{L})$ & $\mathrm{F}^{-}(\mathrm{mg} / \mathrm{L})$ & $\mathrm{Fe}(\mathrm{mg} / \mathrm{L})$ & $\mathrm{Al}(\mathrm{mg} / \mathrm{L})$ & $\operatorname{Mn}(\mathrm{mg} / \mathrm{L})$ & $\mathrm{Zn}(\mathrm{mg} / \mathrm{L})$ & $\mathrm{Cu}(\mathrm{mg} / \mathrm{L})$ & $\mathrm{Cd}(\mathrm{mg} / \mathrm{L})$ & $\mathrm{Cr}(\mathrm{mg} / \mathrm{L})$ \\
\hline \multirow[t]{4}{*}{ R6 } & 12.41 & 0.4 & 128.705 & 15.1400 & 0.9827 & 0.4142 & 0.020 & 0.014 & 0.0009 \\
\hline & 10.98 & 0.3 & 108.350 & 13.9800 & 0.6835 & 0.3578 & 0.015 & 0.014 & 0.0007 \\
\hline & 10.07 & 0.3 & 103.416 & 13.0400 & 0.6216 & 0.3254 & 0.011 & 0.013 & 0.0008 \\
\hline & 12.97 & 0.6 & 128.312 & 15.5470 & 0.8022 & 0.4756 & 0.030 & 0.019 & 0.0010 \\
\hline \multirow[t]{4}{*}{$\mathrm{R} 7$} & 7.09 & 0.2 & 0.288 & 0 & 0.4709 & 0.0090 & 0.008 & 0.003 & 0.0001 \\
\hline & 6.35 & 0.2 & 0.261 & 0 & 0.3978 & 0.0075 & 0.008 & 0.002 & 0.0001 \\
\hline & 5.93 & 0.2 & 0.212 & 0 & 0.3029 & 0.0068 & 0.009 & 0.002 & 0.0001 \\
\hline & 7.35 & 0.1 & 0.285 & 0 & 0.4879 & 0.0120 & 0.009 & 0.004 & 0.0002 \\
\hline \multirow[t]{4}{*}{$\mathrm{R} 8$} & 14.18 & 0.3 & 0.517 & 0.0989 & 0.0066 & 0.0023 & 0.005 & 0.005 & 0.0004 \\
\hline & 13.05 & 0.2 & 0.332 & 0.0900 & 0.0065 & 0.0020 & 0.001 & 0.004 & 0.0000 \\
\hline & 12.24 & 0.2 & 0.298 & 0.0850 & 0.0061 & 0.0014 & 0.002 & 0.003 & 0.0002 \\
\hline & 14.41 & 0.3 & 0.580 & 0.1000 & 0.0072 & 0.0027 & 0.002 & 0.006 & 0.0005 \\
\hline
\end{tabular}

Acknowledgements The authors wish to thank the financial support provided by the National Natural Science Foundation of China (41977159).

Author's contribution The submission has been received explicitly from all co-authors. And authors whose names appear on the submission have contributed sufficiently to the scientific work and therefore share collective responsibility and accountability for the results.

\section{Declaration}

Conflict of interest The authors declare that they have no conflict of interest. This article does not contain any studies with human participants or animals performed by any of the authors. Informed consent was obtained from all individual participants included in the study.

Ethical approval I certify that this manuscript is original and has not been published and will not be submitted elsewhere for publication while being considered by International Journal of Coal Science \& Technology. And the study is not split up into several parts to increase the quantity of submissions and submitted to various journals or to one journal over time. No data have been fabricated or manipulated (including images) to support our conclusions. No data, text, or theories by others are presented as if they were our own.

Open Access This article is licensed under a Creative Commons Attribution 4.0 International License, which permits use, sharing, adaptation, distribution and reproduction in any medium or format, as long as you give appropriate credit to the original author(s) and the source, provide a link to the Creative Commons licence, and indicate if changes were made. The images or other third party material in this article are included in the article's Creative Commons licence, unless indicated otherwise in a credit line to the material. If material is not included in the article's Creative Commons licence and your intended use is not permitted by statutory regulation or exceeds the permitted use, you will need to obtain permission directly from the copyright holder. To view a copy of this licence, visit http://creativecommons. org/licenses/by/4.0/.

\section{References}

Acikel S, Ekmekci M (2018) Assessment of groundwater quality using multivariate statistical techniques in the Azmak Spring Zone, Mugla. Turk Environ Earth Sci 77:753

Appelo CAJ, Postma D (2005) Geochemistry, groundwater and pollution, 2nd edn. CRC Press, Florida

Atanackovic N, Dragisic V, Stojkovic J et al (2013) Hadrochemical characteristics of mine waters from abandoned mining sites in Serbia and their impact on surface water quality. Environ Sci Pollut Res Int 20(11):7615-7626

Baena-Moreno FM, Rodríguez-Galán M, Arroyo-Torralvo $\mathrm{F}$ et al (2020) Low-energy method for water-mineral recovery from acid mine drainage based on membrane technology: Evaluation of inorganic salts as draw solutions. Environ Sci Technol 54(17): 10936-10943

Huang BX, Liu JW, Li N et al (2017) Framework of the theory and technology for mine closure. J Ch Univ Min Technol 46(4): $715-729,747$

Brantner JS, Senko JM (2014) Response of soil-associated microbial communities to intrusion of coal mine-derived acid mine drainage. Environ Sci Technol 48(15):8556-8563

Cain MK, Zhang Z, Yuan KH (2017) Univariate and multivariate skewness and kurtosis for measuring nonnormality: Prevalence, influence and estimation. Behav Res Methods 49(5):1716-1735

Feng CC, Han ZT, Zhang ZY et al (2010) Mine water pollution and acid mine water treatment. Coal Technol 29(5):12-14

Digesti RD, Weeth HJ (1976) A defensible maximum for inorganic sulfate in drinking water of cattle. J Anim Sci 42(6):1498-1502

Doric D, Nikolic-Doric E, Jevremovic V et al (2009) On measuring skewness and kurtosis. Qual Quant 43(3):481-493

Eduardo G, Celso CM, Sandra MM (2013) A study employing different clays for $\mathrm{Fe}$ and $\mathrm{Mn}$ removal in the treatment of acid mine drainage. Water Air Soil Pollut 224(01):1401.1-1401.11

Exley C (2012) Reflections upon and recent insight into the mechanism of formation of hydroxy aluminosilicates and the therapeutic potential of silicic acid. Coord Chem Rev 256(1-2):82-88

Fan LM, Ma LQ, Yu YH et al (2019) Water-conserving mining influencing factors identification and weight determination in 
northwest China. Int J Coal Sci Technol 6(1):95-101. https://doi. org/10.1007/s40789-018-0233-2

Gomez GG, Sandler RS, Seal E (1995) High levels of inorganic sulfate cause diarrhea in neonatal piglets. J Nutr 125(9):2325-2332

He B, Li ZN, Dong YR et al (2018) Static leaching law of main pollution components of coal gangue. Bull Ch Ceram Soc 37(4):1441-1446,1461

Zhao HY, Li YH, Song Q et al (2016) Leaching characteristics of coal gangue in a new dynamic cyclic leaching device. Ch Environ Sci 36(7):2090-2098

Li H, Zha JJ, Sun QY (2019) Effects of acid mine drainage on the abundance of functional genes involved in nitrogen cycle in soil profiles. Biotechnol Bull 35(6):7-14

Larseen L, Garmichad GR (2000) Acid rain and acidification in China: The importance of base canon deposition. Environ Pollut 110(1):89-102

Masindi V (2016) A novel technology for neutralizing acidity and attenuating toxic chemical species from acid mine drainage using cryptocrystalline magnesite tailings. Water Process Eng 10:67-77

Masindi V, Gitari MW, Tutu H et al (2016) Fate of inorganic contaminants post treatment of acid mine drainage by cryptocrystalline magnesite: Complimenting experimental results with a geochemical model. J Environ Chem Eng 4(4):4846-4856

Mosley LM, Biswas TK, Dang T et al (2018) Fate and dynamics of metal precipitates arising from acid drainage discharges to a river system. Chemosphere 212:811-820

Nisarat S, Thitiporn S, Khanitta K et al (2015) Additional burden of diseases associated with cadmium exposure: A case study of cadmium contaminated rice fields in Mae Sot District, Tak Province, Thailand. Int $\mathbf{J}$ Environ Res Public Health 12(8):9199-9217

Nordstorm DK, Alpers CN (1999) Geochemistry of acid mine waters. In: Plumlee GS, Logsdon MJ (eds) The environmental geochemistry of mineral deposits, part A. Processes, techniques and health issues: society of economic geologists. Rev. Econ. Geo, 6A: $133-156$

Nordstrom K, Blowes DW, Ptacek CJ (2015) Hydrogeochemistry and microbiology of mine drainage: An update. Appl Geochem $57: 3-16$

Ogunlaja A, Ogunlaja OO, Okewole DM (2019) Risk assessment and source identification of heavy metal contamination by multivariate and hazard index analyses of a pipeline vandalized area in Lagos State, Nigeria. Sci Total Environ 651:2943-2952
Park I, Tabelin CB, Jeon S et al (2019) Review of recent strategies for acid mine drainage prevention and mine tailings recycling. Chemosphere 219:588-606

Rahimzadeh MR, Kazemi S, Moghadamnia AA (2017) Cadmium toxicity and treatment: An update. Caspian J Intern Med $8(3): 135-145$

Rashed MN (2010) Monitoring of contaminated toxic and heavy metals, from mine tailings through age accumulation, in soil and some wild plants at Southeast Egypt. J Hazard Mater 178(1/ 3):739-774

Selvakumar S, Chandrasekar N, Kumar G (2017) Hydrogeochemical characteristics and groundwater contamination in the rapid urban development areas of Coimbatore, India. Water Resour Ind $17: 26-33$

Silva AM, Lima RMF, Leao VA (2012) Mine water treatment with limestone for sulfate removal. J Hazard Mater 221-222:45-55

Soucek DJ, Kennedy AJ (2005) Effects of hardness, chloride, and acclimation on the acute toxicity of sulfate to freshwater invertebrates. Environ Toxicol Chem 24(5):1204-1210

Tolonen ET, Sarpola A, Hu T et al (2014) Acid mine drainage treatment using by-products from quicklime manufacturing as neutralization chemicals. Chemosphere 117:419-424

Ullrich SR, González C, Poehlein A et al (2016) Gene loss and horizontal gene transfer contributed to the genome evolution of the extreme acidophile "Ferrovum." Front Microbiol 7(390):797

Wang XW, Zhao NN, Han XY (2013) Leaching pollution characteristics of polycyclic aromatic hydrocarbons from piled coal gangue. Ch J Environ Eng 7(9):3594-3600

Xie HP, Gao MZ, Gao F et al (2017) Strategic conceptualization and key technology for the transformation and upgrading of shutdown coal. J China Coal Soc 42(6):1355-1365

Yu XY (2018) The effects of applying lime and biochar on the growth and nutrient uptake of Phaseotus Calcaltus Roxb in acid soils. Southwest University.

Yuan JH, Xu RK (2012) Research progress of amelioration effects of biochars on acid soils. Soils 44(4):541-547

Yu H, Gui HR, Zhao HH et al (2020) Hydrochemical characteristics and water quality evaluation of shallow groundwater in Suxian mining area, Huaibei coalfield. Ch Int J Coal Sci Technol 7(4):825-835. https://doi.org/10.1007/s40789-020-00365-6

Zhu P, Liang X, Wang P et al (2016) Assessment of dietary cadmium exposure: A cross-sectional study in rural areas of south China. Food Control 62:284-290 